\title{
NEW ZEALAND EARTHQUAKES AND PLATE TECTONIC THEORY
}

\author{
R.I. Walcott*
}

\section{ABSTRACT}

The rates and direction of shear strain from geodetic data and the direction of slip from earthquake mechanism studies in New zealand are in good agreement with plate tectonic theory. The relative motion of the Pacific and Indian plates in the last 100 years has been accommodated by distributed strain in a belt at least $100 \mathrm{~km}$ wide crossing New Zealand from north-east to south-west. Strain rates within this belt exceed $3 \times 10^{-7} / \mathrm{y}$ and average $5 \times 10^{-7} / \mathrm{y}$ in Marlborough.

Under the eastern North Island and northern part of the South Island the Pacific plate underthrusts the overlying belt of deformation. Large thrust earthquakes are episodically generated, perhaps by locking of the thrust. Not all relative plate movement is transformed into displacement on faults - a substantial fraction is taken up by aseismic and anelastic deformation within the plate boundary zone. The relative proportion of aseismic and seismic deformation may vary in different regions.

\section{INTRODUCTION}

Geophysics Division, D.S.I.R., has published a number of papers in recent years, loosely within the framework of the Earth Deformation Programme initiated by the Royal Society of New zealand in 1973, that may assist in understanding the processes that lead to earthquakes in New Zealand. While the research is continuing, now is a suitable time to summarise some of the conclusions and current ideas. Most of the findings and data have been published elsewhere in the papers cited in the text. The purpose of the present article is to present a review of these studies for the broader readership of the N.Z. National Society for Earthquake Engineering.

The theory of plate tectonics, formulated around 10 years ago, arose in large part as an explanation for the global distribution and mechanisms of earthquakes. Earthquakes are generally restricted to continuous lineaments that divide the earth's surface into a mosaic of 'plates' that are themselves comparatively aseismic. As the plates move passively over the surface of the earth earthquakes are generated at their boundaries. With suitable seismometers positioned around an earthquake epicentre it is possible to recognise a pattern of compressional or dilational first motions in the wave train proceeding from the focus so that the mechanism of the earthquake can be inferred. If the orientation of the fault plane is known then the direction of slip can be also obtained. Earthquake mechanisms have assisted in the identification of three classes of boundary between plates that are in good agreement with other geological and geophysical information. These are: Rifts, in which the earthquake mechanism indicates extension normal to the boundary; Subduction zones, where a slab of high seismicity can be recognised dipping steeply from near a trench on the sea floor under

* Geophysics Division, D.S.I.R., Wellington. active andesitic volcanoes to depths of several hundred kilometres; earthquake mechanisms commonly indicate compression normal to the boundary; Transform faults, long steeply dipping faults with lateral offsets of many tens or hundreds of kilometres with earthquake mechanisms of simple shear parallel to the fault. In purely kinematic terms we can refer to these classes as being extensional, compressional or translational boundaries.

The directions of motion across the boundaries between plates can be obtained from the earthquake mechanism and, more importantly, from the trend of transform faults. The rates of motions are given by the separation of linear magnetic anomalies of known age on the sea floor on either side of the mid-oceanic ridges. The separation between the pair of magnetic anomalies identified by the number ' 3 ', formed about 5 million years ago gives the average rate in the last 5 million years. This value is probably a good estimate of the present day rate of plate motion as the rate of separation can be shown to be remarkably uniform in time from older magnetic anomalies. Using this type of information from world wide sources, Chase (1978) has computed the relative plate motion vectors for all major plate boundaries.

The importance of plate tectonics to the study of New Zealand earthquakes is that New zealand lies across the boundary between the Pacific and Indian (or Australian) Plates (Figure 1). According to Chase, the Pacific is moving with respect to the Indian plate around a pole near $60^{\circ} \mathrm{S}$ and $175^{\circ} \mathrm{E}$ at a rate of $1.26^{\circ} /$ million years. This means that in the vicinity of Wellington the Pacific plate is moving due west at a rate of $50 \mathrm{~mm} / \mathrm{y}$, with rates being faster to the north and slower to the south, about 40 and $60 \mathrm{~mm} / \mathrm{y}$ near the latitudes of Dunedin and Auckland respectively. The 95\% confidence limits from Chase's data set would suggest 
that these values are known to about $\pm 7^{\circ}$ in direction and $+5 \mathrm{~mm} / \mathrm{y}$ in rate. It is the stresses developed between the plates that are presumably the ultimate cause of most New Zealand earthquakes. However in moving from a global to a more regional scale it is readily apparent that the simplified classes of plate boundary are not directly applicable. The shallow seismicity of. New Zealand (Figure 2) is diffusely spread over a zone at least $100 \mathrm{~km}$ wide and there are no clear cut discontinuities that might be identified with extensional, compressional or translational boundaries. Moreover the direction of relative plate motion is oblique to the north-east/south-west trend of the boundary indicated by the seismicity so that both compressional and translational

components of motion must be present.

The great success of plate tectonics is that it pulls together an immense amount of information including morphology, tectonics - that is deformation recorded in rocks volcanicity, heat flow, as well as seismicity. But most importantly it is a quantitative theory with the rates and directions of motion being determined. from many independent sources of data. It is in this light that the recent work in Marlborough is very relevant.

\section{GEODETIC STRAIN IN MARLBOROUGH}

Bibby (1975, 1976) compared triangulation surveys made in Marlborough during the period 1875-84 with repeated triangulations made in 1951-60. The triangulation covers almost continuously a broad band from Kaikoura to west of the Wairau valley, a distance of about $100 \mathrm{~km}$ (Figure 3). Changes in the observations of angles give estimates of two components of shear strain and measurements were obtained at a number of localities by combining data in parts of the net (Figure 4). An additional survey made in part of the region in the 1930 's allows examination of the possibility that the shear strain varied in time, but no such variation is apparent. From the data of Figure 4 several points are made. Firstly, there is no difference in strain between triangulations that cross the major faults and those between the faults - the ground is deforming uniformly throughout the area. Secondly, the shear strain component $\gamma_{2}$ is uniform across the full width of the deforming belt from Wairau to Kaikoura and has an average shear strain in the 75 year period between the surveys of $30 \mu r a d$, or a shear strain rate of $4 \times 10^{-7} / \mathrm{y}$. There is a suggestion that the shear strain component $\gamma_{1}$, representing compression normal to the faults, changes from negative values near the wairau to positive values near Kaikoura, indicating an increasing compressional component normal to the faults. On average the $\gamma_{1}$ component has a value of about 20 rad or a strain rate of $3 \times 10^{-7} / y$. If we take the shear strain to be produced by displacement components parallel and normal to the faults then the rate of displacement is $50 \mathrm{~mm} / \mathrm{y}$ in the direction about $270^{\circ}$, in very good agreement with plate tectonic theory. This was one of the first direct, instrumentally observed confirmations of the plate tectonic rates.

\section{NEW ZEALAND WIDE OBSERVATIONS}

Similar estimates of shear strain have been made over much of New Zealand and are reported in Walcott $(1978 \mathrm{a}, 1978 \mathrm{~b})$, Bibby and
Walcott (1977). The two components are shown in Figure 5 as the direction of the principal axis of horizontal compression and the maximum shear strain rate, in units of $10^{-7}$ /year. Throughout the South Island and the southern part of the North Island the orientation of the principal strain axes is about the same, with the principal axis of compression around $100^{\circ}$ azimuth. Rates are high $\left(>3 \times 10^{-7} / \mathrm{y}\right)$ in a broad belt along the trend of the southern Alps, through Marlborough and across Cook Strait to the East Coast of the North Island. There are several measurements in Westland with triangulations that cross the Alpine Fault giving values of around $6 \times 10^{-7} / \mathrm{y}$ and much lower values for triangulations entirely west of the fault. We have a value of $3 \times 10^{-7} / \mathrm{y}$ near Lakes Pukaki and Tekapo and less than $1 \times 10^{-7} / \mathrm{y}$ at points to the east. However we have no data in the vicinity of the Main Divide of the Southern Alps. For the relative movement between the plates to be taken up within the belt between Westland and Lakes Pukaki and rekapo an average strain rate of $7 \times 10^{-7} / \mathrm{y}$ is required over the full width of the belt.

Near Hawkes Bay and Lake Taupo the direction of the principal axis of compression is oriented north-east/south-west, almost at right angles to the trend in the south. This orientation indicates relative extension normal to the trend of the plate boundary. Off the east coast of the North Island is the Hikurangi Trench which lies on the extension of the Kermadec and Tonga trenches. Under the North Island is a slab of high seismicity dipping north-westwards to depths of about $300 \mathrm{~km}$ (Adams and Ware, 1977) (Figure 6). It shallows to depths of around $50 \mathrm{~km}$ under the axial ranges of the Tararua and Ruahine Ranges. A shallow dipping zone of high seismicity can be identified under the east coast of the North Island rising from depths of about $50 \mathrm{~km}$ under the axial ranges at an angle of about $12^{\circ}$ and if extended would reach to the Hikurangi Trench (Figure 8). The active volcanism, seismicity and gravity anomalies of the North Island are all characteristic of a subduction zone and according to plate tectonic theory represents part of the Pacific plate underthrust beneath the overriding Indian plate.

The relative extension we see in the triangulation data is unusual, but is consistent with earthquake mechanims in the crustal rocks overlying the subducted plate. These too show tension axes normal to the boundary. The extension suggests that the Pacific and Indian plates are totally decoupled along the surface of the subducted slab with the relative plate movement being taken up by an aseismic slip on the surface of the slab.

\section{EPISODIC EXTENSION AND COMPRESSION}

Extension normal to the boundary has. not always been the rule, however. Comparisons of triangulation made in the 19 th century with those made about 1931 show a strong component of compression normal to the plate boundary. It is only after the great 1931 Hawke's Bay earthquake that extension became evident.

This earthquake, of magnitude 7.9 (Richter, 1958), evidently originated on a north-westward dipping thrust, with a 


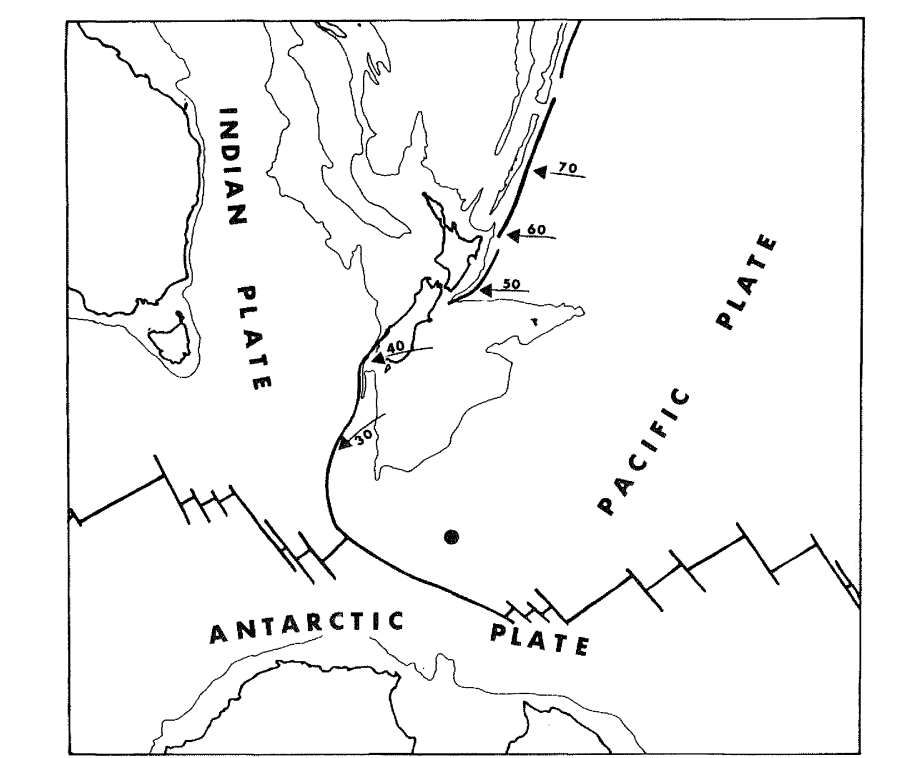

FIGURE 1: PLATES AND PLATE BOUNDARIES NEAR NEW ZEALAND THE ARROWS SHOW THE DIRECTION AND RATE IN MILLIMETRES INDIAN PLATE BACED ON THE CHASE (1978) POLE - THE POSITION OF WHICH IS SHOWN BY THE SOLID CIRCLE

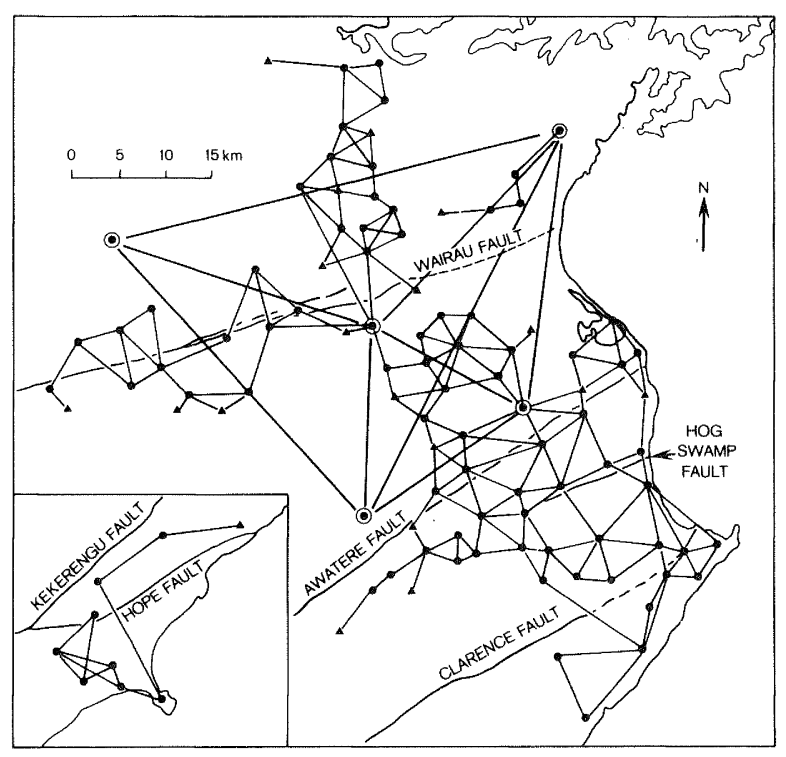

FIGURE 3: THE MARLBOROUGH TRIANGULATION. THE LARGE IN 1938 IS A FIRST ORDER TRIANGULATION FIRSTOBSERVED FIRST OBSERVED IN 1875-1884 AND REPEATED IN 1951-1960. (FROM BIBBY AND WALCOTT, 1977).

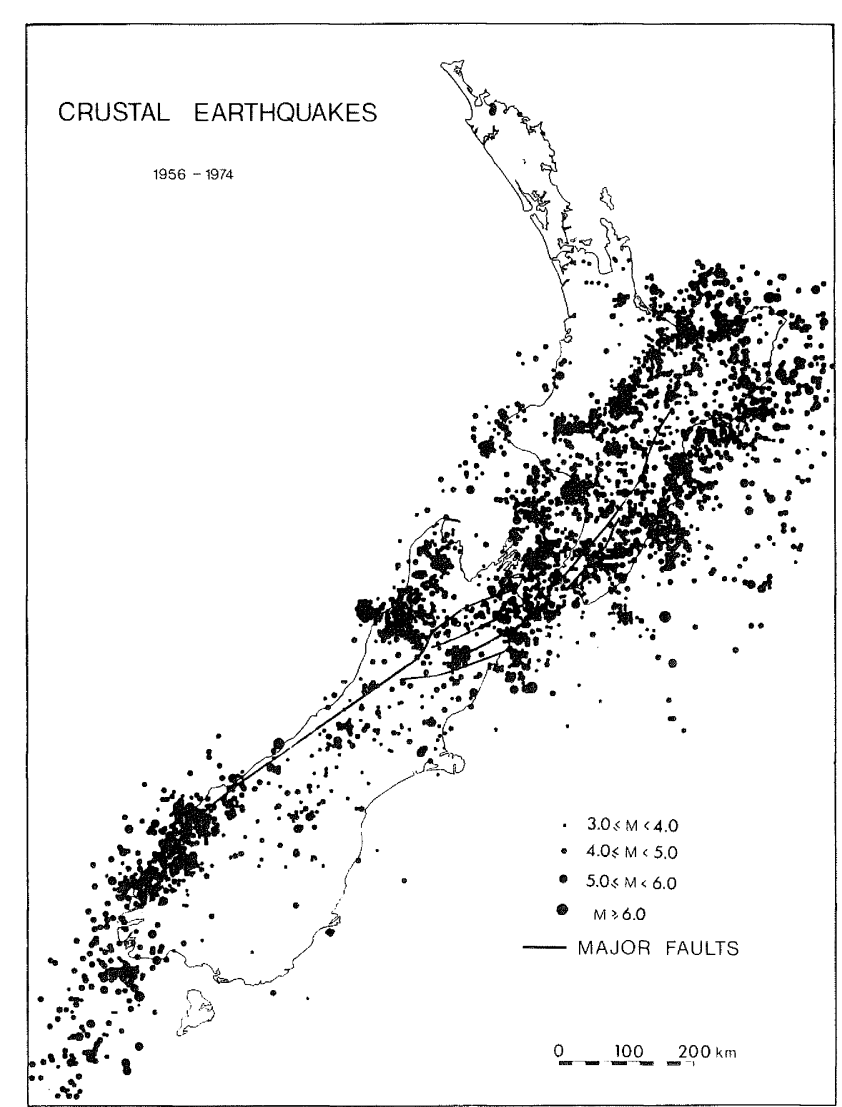

FIGURE 2: SHALLOW SEISMICITY IN NEW ZEALAND FOR A TWENTY YEAR PERIOD. THE EPICENTRES ARE ALL EARTHQUAKES REPORTED IN THE NEW TEALAND SEISMOLOGICAL BULLETINS IN WHICH THE DEPTH OF THE HYPOCENTRE IS RESTRICTED TO 12 


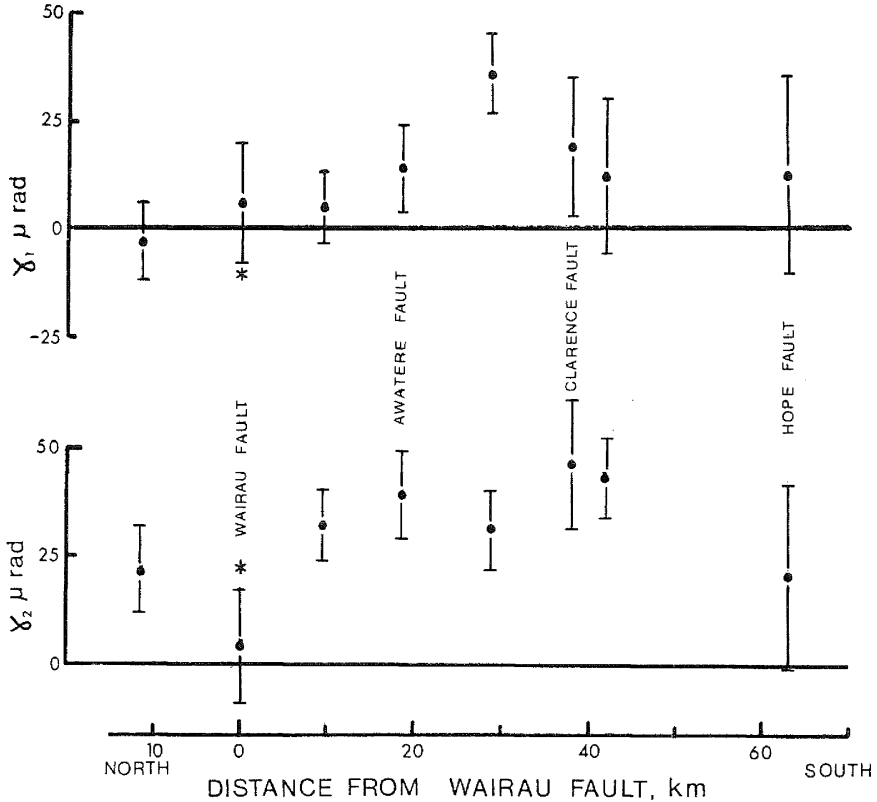

FIGURE 4: SHEAR STRAIN COMPONENTS CALCULATED FROM RETRIANGULATION DATA PLOTTED AGAINST DISTANCE FROM THE WAIRAU FAULT. THE BARS SHOW STANDARD ERROR. (FROM BIBBY, 1976)

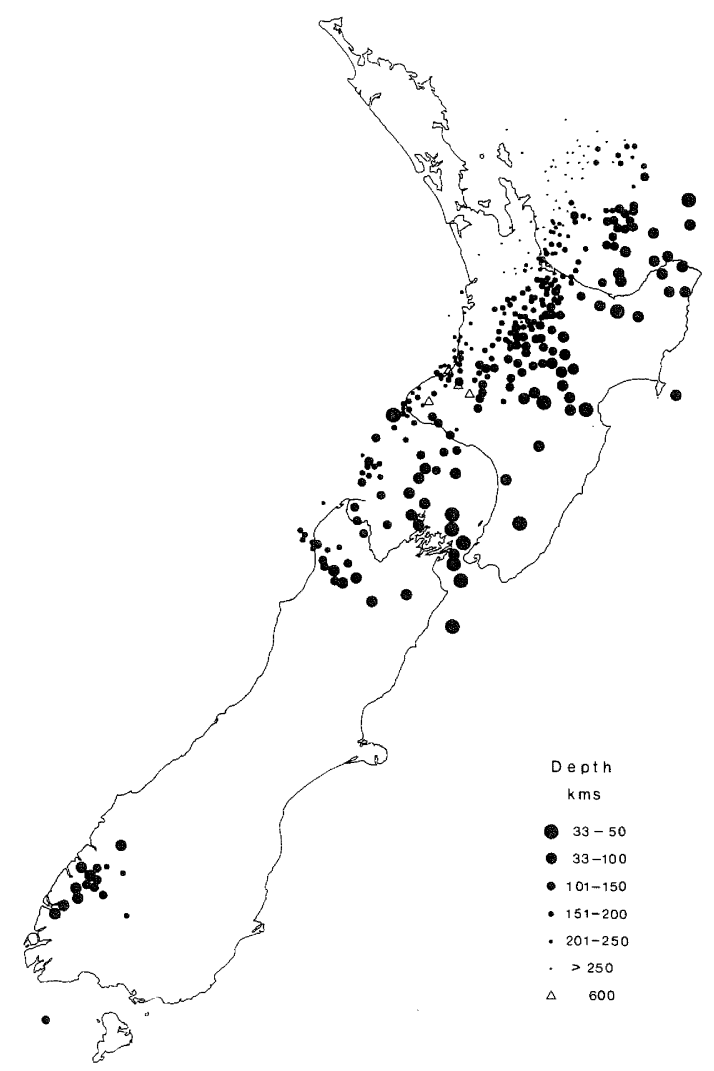

FIGURE 6: INTERMEDIATE AND DEEP EARTHQUAKES IN NEW ZEALAND, REDRAWN FROM ADAMS AND WARE, 1977 AND SMITH, 1972. UNDER THE NORTH ISLAND EARTHQUAKE HYPOCENTRES DEEPEN TO THE NORTH-WEST AND DEFINE A NORTH-EAST/SOUTH-WEST STRIKING SIAB TO THE NORTH. NORTH-EAST/SOUTH-WEST STRIKING SLAB. TO THE NORTHEAST THE EARTHQUAKES CONTINUE ALONG THE KERMADEC
AND TONGA TRENCH. TO THE SOUTH-WEST THEY END ABRUPTLY AT A LINE BETWEEN KAIKOURA AND NORTH-WEST NELSON

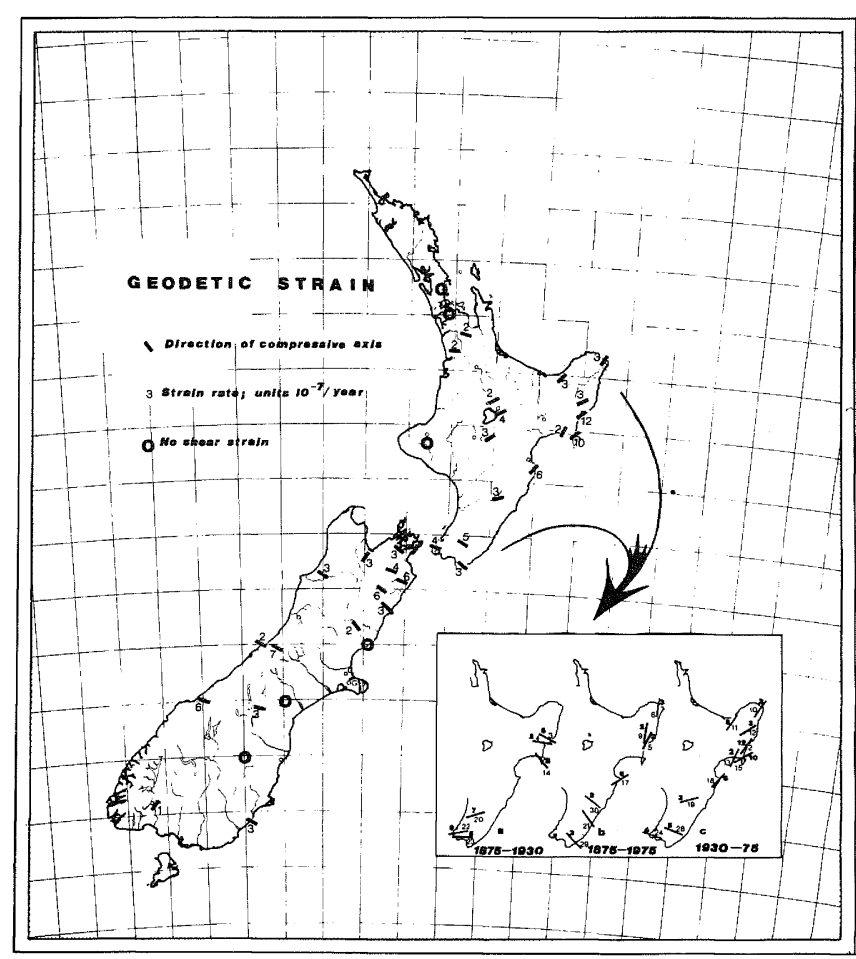

FIGURE 5: MAXIMUM SHEAR STRAIN RATE (IN UNITS OF $10-7 / Y)$ AND DIRECTIONS OF THE PRINCIPAL AXIS OF COMPRESSION IN NEW ZEALAND. THE INSERT SHOWS RESULTS FOR THREE DIFFERENT PERIODS BETWEEN THE INITIAL AND THE REPEATED TRIANGULATION A,1875-1930 B, 1875-1975 AND C, 1930-1975.

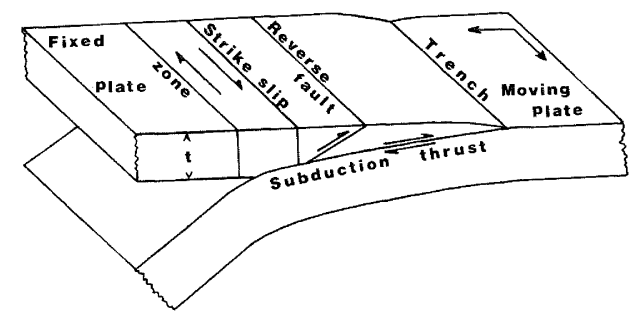

FIGURE 7: MODEL OF THE SUBDUCTED PLATEAND OVERLYING CRUST OF EASTERN NORTH ISLAND, NEW ZEALAND. (FROM WALCOTT, 1978B) 
geodetically determined north-west/south-east shortening of about 3 metres. The principal axis of compression at the time of the earthquake was $125^{\circ}$ in azimuth, like that of the survey strain prior to the earthquake. A large earthquake in the following year at Wairoa showed a principal axis of compression more like those of the present day, around $70^{\circ}$. It was also observed that both before and after the earthquake there was a continuing simple shear strain parallel to the boundary in the geodetic data.

These observations lead to the hypothesis of episodic compressional and extensional phases within the crust overlying the subduction zone along the east coast of the North Island. The simplified structure may look something like that of Figure 7. The motion of the Pacific plate (on the right) with respect to the Indian plate (left) is oblique to the boundary with both parallel and normal components. The parallel component is accommodated by continuous shear strain in steeply dipping fault and shear zones cutting through the overlying crust. The normal component is today taken up by creep or aseismic slip along the subduction thrust. But periodically the subduction thrust locks and the compressional component between the plates is taken up by a compressional strain in the overlying rocks. Eventually the continuing compressional strain leads to rupture on steeply dipping faults releasing the stress and unlocking the subduction thrust for a new phase of aseismic slip.

Episodic compressional and extensional behaviour may also have occurred in the vicinity of Wellington. Repeated surveys in the Wairarapa and near Wellington City since around 1920 show a principal axis of compression oriented at about $115^{\circ}$ with a compressional component normal to the trend of the plate boundary. But a repeated survey in the Tararua Ranges 1880-1912 show a compression axis of $0700^{\circ}$ indicating a component of extension normal to the faults. Unfortunately this particular triangulation has not been repeated since 1912 so there may be an element of geographic rather than time variation indicated. Surveys near Wellington City in the periods 1912-1931 and 1914-1929 show a principal axis of compression much more nearly east-west than the later north-west/south-east. Together these data may be interpreted as indicating substantial extension normal to the boundary prior to 1920 and substantial compression after that time. The extensional phase suggests that the subduction thrust was unlocked, perhaps following the 1855 Wairarapa earthquake, and that the thrust became locked for some reason around 1920 . the relative plate movement since that time has been accumulating as strain in the overlying crust. The total plate movement in the last 60 years that has accumulated at strain within the crust is about 3 metres, quite sufficient to produce a major earthquake.

\section{SEISMICITY OF THE WELLINGTON REGION}

A permanent telemetered network of sensitive seismometers has been in operation near Wellington since January 1976 with the objective of studying in detail the spatial and time varying distribution of local earthquakes. An analysis of the results to date is given by Robinson (1978). A plot of earthquake epicentres observed in the period January 1976 to September 1977 is shown in Figure 8 and a plot of the depth of earthquakes in north-west/south-east profile in Figure 9. The activity is generally diffuse (Figure 8 ) and the pattern does not vary much in time. The shallow seismicity $(<20 \mathrm{~km})$ does not correlate with major surface faults, a common feature in New Zealand seismicity. In profile the majority of events define a band of relatively intense activity at depths of from 20 to $40 \mathrm{~km}$ dipping gently to the north-west. Presumably this band marks some surface near the top of the underthrust Pacific Iithosphere. The earthquake mechanism of the shallow events well above the band of high activity is a mixture of strike-slip and thrust faulting with the principal axis of compression being horizontal and oriented north-west/ south-east, in good agreement with the post 1920 geodetic data. The earthquake mechanism for the deeper events - below the band of high activity - is extensional with the principal axis of extension in the plane of the dipping slab and trending north-west/south-east. We can explain this pattern as being the result of locking the subduction thrust with the driving force being the pull from the weight of the subducted slab acting against the overlying crust, coupled through the locked zone (Figure 10).

The subducted Pacific lithosphere extends no further south than a line from Kaikoura to north-west Nelson as the intermediate depth earthquakes of the Hikurangi subduction zone are found only north of this line (Figure 6). Much further south, near Fiordland, intermediate depth earthquakes also occur (Smith, 1971) and these are probably related to a subducted Indian plate beneath the Fiordland crust. Between the two subduction zones the relative motion between the Pacific and Indian plates is taken up within the belt of deformation between canterbury and Westland, and the component of compression is manifest in the rise of the southern Alps. Episodic compression and extension presumably applies only to the mode of deformation in the vicinity of the subduction zone. In the South Island compression is continuous.

\section{RATE AND FREQUENCY OF EARTHQUAKES}

This raises the important matter of relating the rate and frequency of earthquakes to the rates of earth deformation from geodetic data and plate tectonics. Earthquakes can be viewed as converting regional strain into discrete displacements on faults. How much of the strain is converted through earthquakes into fault displacements and how much of the strain is dissipated by aseismic processes? The folding and bending observed in rocks of comparatively young geological age is essentially the product of a non-elastic and presumably aseismic process so that some of the deformation is accommodated without the release of seismic energy. Also aseismic creep on faults like that inferred for the subduction thrust at Hawkes Bay, and observed in California, may occur in crustal rocks. 
We have two lines of evidence to suggest that a very substantial part of the strain observed geodetically is accommodated by anelastic processes.

1. In Marlborough, Lensen (1975) has observed that the total offset of data features across the major faults amounts to no more than $16 \pm 2 \mathrm{~mm} / \mathrm{y}$ displacement rate but the geodetic and plate tectonic rate is three times this at around $50 \mathrm{~mm} / \mathrm{y}$. As some of these offsets may have been caused by aseismic creep this suggests that less than one third of the strain will be eventually liberated by earthquakes on these faults.

2. The map of shallow seismicity (Figure 2) shows the seismic activity of the Southern Alps to be comparatively weak. Moreover no earthquake of magnitude greater than 7 has occurred in this region in the last 150 years. Yet we would infer from the geodetic data and plate tectonic theory that the strain rate is as high, if not higher, there than in Marlborough. One interpretation is that the seismicity of the last 150 years is not a good guide to long term seismicity and eventualiy major earthquakes may occur to liberate the accumulated elastic strain. An alternative explanation is that the seismicity has always been low in this region and that only a very small fraction of the strain will ever be released as an earthquake, perhaps less than one tenth as the rocks are deforming in a ductile manner.

At this stage there is no clear evidence to choose between the two hypotheses. Clearly the answer to this question has a bearing on the likelihood of an earthquake in the wellington region. For although the $3 \mathrm{~m}$ compression imposed since the inferred locking of the subduction zone is sufficient to cause a major earthquake only a small fraction of the compression may be available as stored elastic strain and most may be dissipated by anelastic processes like rock folding.

\section{ACKNOWLEDGEMENTS}

Figures $2,7,8,9$ and 10 have been reproduced with permission from articles originally published in the Geophysical Journal of the Royal Astronomical Society.

\section{REFERENCES}

Adams, R. D. and D. E. Ware. "Subcrustal earthquakes beneath New Zealand; Locations determined with a Laterally Inhomogeneous Velocity Model", N.Z. Jour. Geol. Geophys., $20,59-83,1977$.

Bibby, H. M. "Crustal Strain from Triangulation in Marlborough, New Zealand". Tectonophysics, 29, 529-540, 1975.

Bibby, H. M. "Crustal Strain Across the Mariborough Faults, New Zealand". N.Z. J. Geol. Geophys., 19, 407-425, 1976.

Bibby, H. M. and R. I. Walcott. "Earth Deformation and the Triangulation of New Zealand". N.Z. Surveyor, 28, 741, 1977.

Chase, C. G. "Plate Kinematics : the Americas, East Africa and the rest of the World", Earth and Planetary Sciences Letters, 37, $353-368,1978$.

Lensen, G. J. "Earth Deformation Studies in New Zealand". Tectonophysics, 29, $541-551,1975$.
Richter, C. F. "Elementary Seismology", W. H. Freeman, San Francisco, Calif., 1958.

Robinson, Russell. "Seismicity Within a Zone of Plate Convergence - The Wellington Region, New Zealand". Geophys. J. R. Astro. Soc. 55, 693-702, 1978.

Smith, W. D. "Earthquakes at Shallow and Intermediate Depth in Fiordland, New Zealand". J. Geophys. Res., 76, 4901-4907, 1971 .

Walcott, R. I. "Present Tectonics and Late Cenozoic Evolution of New Zealand". Geophys. J. R. Astro. Soc., 52, 137-164, $1978 \mathrm{a}$.

Walcott, R. I. Geodetic Strains and Large Earthquakes in the Axial Tectonic Belt, New Zealand". J. Geophys. Res., 83, 4419$4429,1978 \mathrm{~b}$.

Paper received $30 \mathrm{March}, 1979$. 


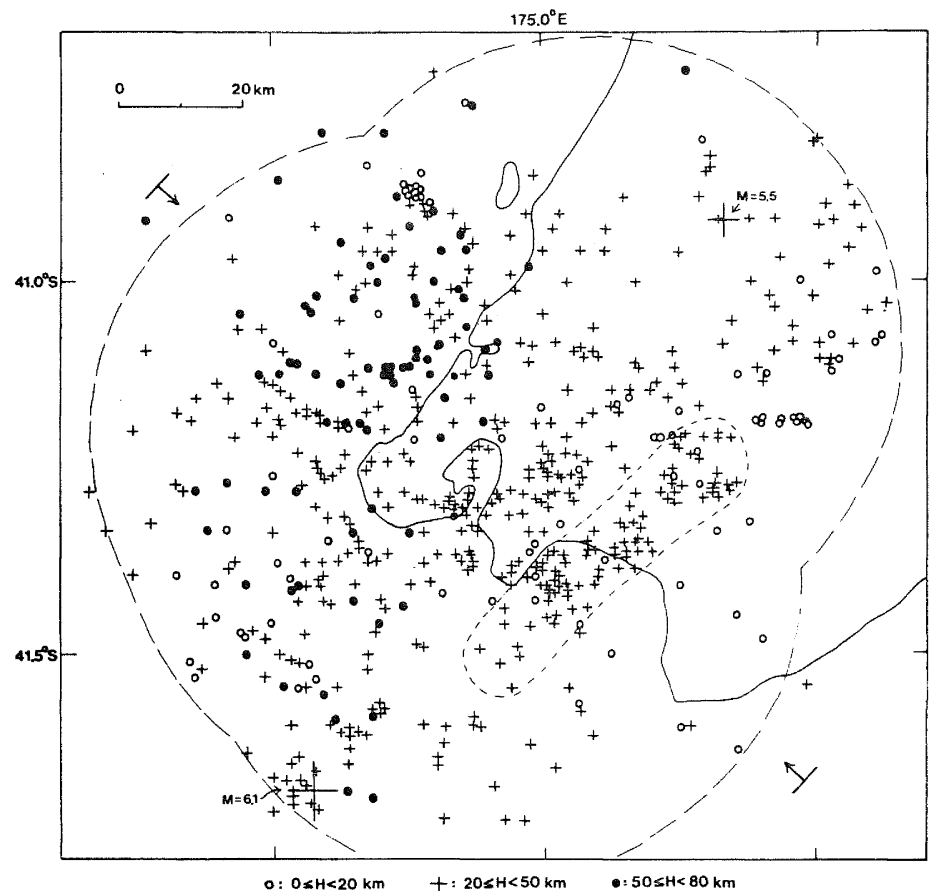

FIGURE 8: EPICENTRES DETERMINED BY THE WELLINGTON NETWORK IN THE PERIOD JANUARY 1976 TO SEPTEMBER 1978. DASHED OUTER BOUNDARY REPRESENTS A LIMIT BEYOND WHICH HYPOCENTRES WERE GENERALLY NOT DETERMINED. THE LOCATIONS OF THE TWO LARGEST EVENTS ARE INDICATED. (FROM ROBINSON, 1978).

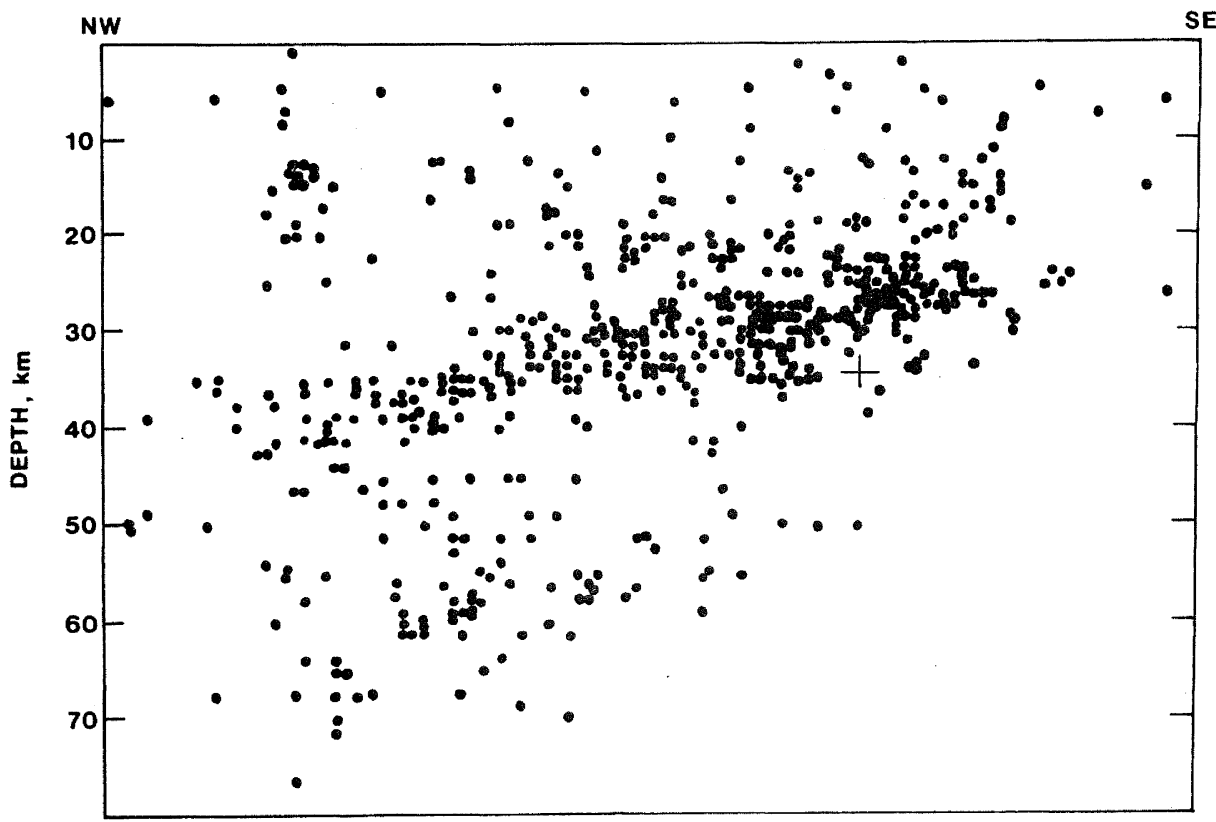

FIGURE 9: CROSS-SECTION OF THE EVENTS OF FIGURE 8 IN THE PROFILE INDICATED BY ARROWS. THE CROSS IS THE LOCATION OF THE MAGNITUDE 6.1 CAPE CAMPBELL EARTHQUAKE. (FROM ROBINSON, 1978).

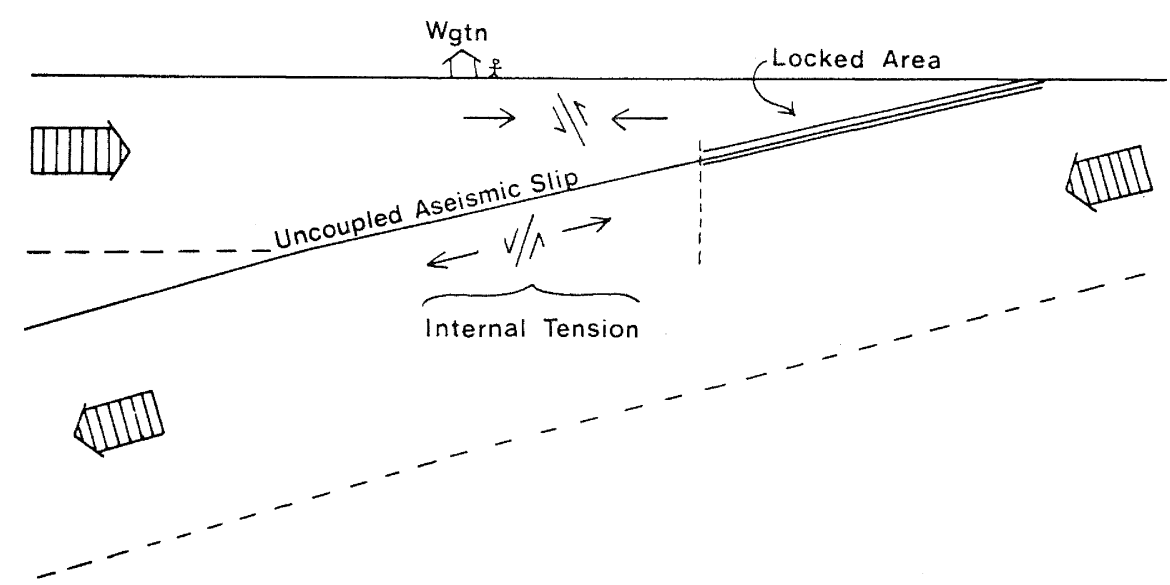

FIGURE 10: SCHEMATIC DRAWING OF THE WELLINGTON REGION. THE LARGE ARROWS REPRESENTS FORCES DUE TO THE LARGE SCALE DRIVING MECHANISM OF PLATE CONVERGENCE WHILE SMALLER ARROWS REPRESENT THE RESULTING STRESS STATES DUE TO A LOCKED REGION EAST OF WELLINGTON RESISTING MOTION. (FROM ROBINSON, 1978). 